\title{
Immunohistochemical expression of TGF $\beta$, E-cadherin and vimentin in benign and malignant neoplasias of canine mammary gland
}

\author{
Erika M Terra ${ }^{1 *}$, Geórgia M Magalhães ${ }^{2}$, Marcela MP Rodrigues ${ }^{3}$, Renée L Amorim ${ }^{4}$, Noeme S Rocha ${ }^{4}$, \\ Mirela T Costa ${ }^{1}$
}

From São Paulo Advanced School of Comparative Oncology

Águas de São Pedro, Brazil. 30 September - 6 October 2012

\section{Background}

Epithelial-mesenchymal transition (EMT) is a fundamental biologic process whereby epithelial cells detach from the surrounding tissue and acquire characteristics of mesenchymal cells, a unique motile, spindle-shaped cell with endto-end polarity. EMT can be induced or regulated by various growth and differentiation factors; among these, TGF $\beta$ has received much attention as a major inducer of EMT during embryogenesis, cancer progression and fibrosis. Our aim was to correlate the immunohistochemical expression of TGF $\beta$, e-cadherin and vimentin in canine mammary tumors.

\section{Materials and methods}

A total of 52 canine mammary tumors, among adenomas $(\mathrm{G} 1, \mathrm{n}=12)$, non-metastatic carcinomas $(\mathrm{G} 2, \mathrm{n}=24)$ and metastatic carcinomas $(G 3, n=16)$, were used to evaluate the immunohistochemical expression of TGF $\beta 1$, E-cadherin and vimentin. Fisher's Exact Test was used for statistical analysis.

\section{Results}

E-cadherin was not differentially expressed in the three tumor groups. Vimentin expression was significantly higher in malignant neoplasias (G1 vs. G2, $p=0.019$ ) and (G1 vs. G3 $p=0.006$ ), with no difference in cases with and without metastasis. The expression of TGF $\beta$ was significantly higher in adenomas compared to metastatic carcinomas $(p=0.01)$. There was no difference between adenomas and non-metastatic carcinomas.

\section{Conclusion}

The pathogenesis and the progression of numerous cancers have been attributed, at least in part, to disruption of normal TGF $\beta$ signaling. Here, we found that decreased expression of TGF $\beta$ in metastatic carcinomas was accompanied by the acquisition of a mesenchymal phenotype, raising the possibility that this cytokine may be involved in EMT in canine mammary neoplasias.

\section{Financial support}

FAPESP.

\section{Author details}

${ }^{1}$ Department of Clinics and Veterinary Surgery, UNESP, Jaboticabal, SP, Brazil.

${ }^{2}$ Department of Veterinary Pathology, UNESP, Jaboticabal, SP, Brazil.

${ }^{3}$ Department of Urology, Faculty of Medicine, UNESP, Botucatu, SP, Brazil.

${ }^{4}$ Department of Veterinary Pathology, UNESP, Botucatu, SP, Brazil.

Published: 4 April 2013

\section{doi:10.1186/1753-6561-7-S2-P20}

Cite this article as: Terra et al:: Immunohistochemical expression of

TGF $\beta$, E-cadherin and vimentin in benign and malignant neoplasias of canine mammary gland. BMC Proceedings 2013 7(Suppl 2):P20.

* Correspondence: erikamterra@hotmail.com

${ }^{1}$ Department of Clinics and Veterinary Surgery, UNESP, Jaboticabal, SP, Brazil

Full list of author information is available at the end of the article

(c) 2013 Terra et al; licensee BioMed Central Ltd. This is an Open Access article distributed under the terms of the Creative Commons 